\title{
REVELATION OF NATURE-MINDED TRAVELERS: A STUDY OF THE SWEDISH
}

\author{
JOSEPH S. CHEN,* NINA K. PREBENSEN,† YA-LING CHEN,* AND HYANGMI KIM* \\ *Department of Recreation, Park and Tourism Studies, Indiana University at Bloomington, \\ Bloomington, IN, USA \\ †Tromso University Business School, Tromso, Norway
}

\begin{abstract}
This research delineates the underlying markets of Swedish travelers visiting nature-based destinations in Norway. A total of 2,034 respondents are partitioned into mutually exclusive groups, based on the following four nature-related travel motivations: (1) to experience Norwegian nature, (2) to be active in nature, (3) to travel in a country that takes the environment seriously, and (4) to get close to nature. Consequently, the study reveals three distinct groups: (1) the Hardcore Explorer, (2) the Typical Participant, and (3) the Casual Seeker. All groups noted their most important motivation in this travel is "to experience the beautiful Norwegian nature." While the Casual Seeker, which represents the smallest cluster, does not regard nature as the main attractor to Norway, the other two clusters are more likely to be motivated by their interest in nature. Relevant discussions and suggestions for future studies are provided in the conclusion.
\end{abstract}

Key words: Nature-based tourism; Motivation; Swedish; Norway

\section{Introduction}

As the built environment moves toward urbanization, inhabitants have gradually lost touch with nature. In response to such a void, nature-based tourism renders a recreational venue in which urban dwellers could amply interact with nature. Vickerman (1988) enunciated that natural environments are a pivotal ingredient for enticing tourists to destinations. Hull and Harvey (1989) further articulated certain personal benefits of interacting with nature, including the change of emotion in a positive fashion.
Although tourism scholars have studied naturebased tourism in the last two decades, it is not clear if all of these visitors are attracted by nature. It may be assumed that the attitudes of tourists in exploring nature will vary. For example, some may be highly interested in engaging with nature and some may show a low motive toward involvement in natural environments. It is thus plausible to further examine the characteristics of tourists who hold a different level of motivation toward exploring nature. This research attempts to understand the characteristics of tourist segments possessing different 
levels of trip motivation toward nature. This article uses a case study approach that focuses on the trip behaviors of a single nationality at a particular setting, that of Swedish outbound tourists traveling to Norway, a country that is well known for spectacular scenery and nature-based activities (Gössling \& Hultman, 2006; Snyder \& Stonehouse, 2007).

Butler (1994) stated that natural environments allow travelers to enjoy themselves by offering opportunities for outdoor activities and adventure. In a discussion on tourist experience in more unusual or dramatic attractions, Viken (1993) claimed that people regard the Arctic as a paradise for viewing nature. According to the analysis of international traveler motivations for visiting global destinations, approximately $40-60 \%$ are nature tourists in some countries (Fillion, Foley, \& Jacquemot, 1994). Further, the World Tourism Organization (1998) found that all types of nature-related tourism visits contribute to approximately $20 \%$ of the total inbound tourism industry, with an estimated value of nearly $\$ 20$ billion annually, presenting an estimated annual growth rate of approximately $10 \%$ (The International Ecotourism Society, 2000).

There is no universal definition of nature-based tourism. A great deal of tourism activities could be described as nature-based tourism as long as the natural environment is the factor attracting tourists to specific destinations (Valentine, 1992). Several researchers have attempted to describe the scope of nature-based tourism. For example, Valentine (1993) summarized several terminologies that refer to nature-based tourism, including nature travel, natured-oriented tourism, environment-friendly tourism, alternative tourism, ecotourism, and green tourism. More specifically, nature-based tourism is defined by Valentine (1992) as tourism "primarily concerned with the direct enjoyment of some relatively undisturbed phenomenon of nature" (p. 108). Moreover, Goodwin (1996) viewed nature-based tourism as a holistic concept entailing various forms of tourism, such as adventure tourism, low-impact tourism, and ecotourism. Goodwin (1996) was concerned with the associated tourism impact that some recreational and cultural activities might involve, where only some of them will make a positive impact on conservation. The above conceptual definitions, in general, touch on recreational elements of tourist engagement. Within the environmental movement, new ideas and initiatives have surfaced to mitigate any negative impacts caused by tourist development. For example, ecotourism is defined as "responsible travel to natural areas that conserves the environment and improves the well being of local people" (The International Ecotourism Society, 1990). Earlier literature identified some essential differences of concept development between nature-based tourism and ecotourism (Goodwin, 1996). Nevertheless, the academic community is not able to reach a consensus in defining nature-based tourism (Mehmetoglu, 2007; Tangeland, Vennesland, \& Nybakk, 2013). Moreover, Nyaupane (2007) discovered that tourists visiting both natural and ecotourism destinations are not able to find any significant difference in product offerings between the these two types of destinations. The operational definition of nature-based tourism in this study is the type of tourism that tourists utilize and appreciate in exploring natural resources in relatively natural area (Tangeland et al., 2013).

Literature has also reported the characteristics of environment-friendly tourists from marketing perspectives (Dolnicar \& Leisch, 2008; Silverberg, Backman, \& Backman, 1996; Wight, 1996). Dolnicar and Leisch (2008) employed selective marketing techniques and confirmed that destination, motive, moral obligation, attitude, age, and gender preferences are important variables for proenvironmental behaviors. Wright (1996) also profiled ecotourists by their demographic characteristics, trip duration, expenditure patterns, and seasons of travel. Using a similar approach, Silverberg et al. (1996) investigated the psychographic characteristics of nature-based travelers in the southeastern US. They identified the following six clusters of nature-based tourists according to psychographic characteristics: education/history, camping/tenting, relaxation, socializing, information, and viewing nature. Further leisure constraint within the framework of nature-based tourism is another theme investigated by researchers (Nyaupane, Morais, \& Graefe, 2004; Pennington-Gray \& Kerstetter, 2002). Using the leisure constraint theory (Crawford, Jackson, \& Godbey, 1991), which comprises three constraint dimensions of intrapersonal, interpersonal, and structural, Pennington-Gray and Kerstetter (2002) identified money as the most important perceived 
constraint in the context of nature-based tourism, followed by time limitations. In line with Pennington-Gray and Kerstetter's (2002) study, Nyaupane et al. (2004) also revealed that the structural constraint dimension is more complex than previously expected in nature-based tourism studies.

\section{Tourist Motivation}

Motivation is a pivotal aspect of the many psychological properties that can describe tourist behaviors (Crompton, 1979) and influence the functional insight of travelers' decision-making processes (Wight, 1996; Young, 1999). Given that tourism behavior is associated with the complex mechanisms of human nature, it is not easy to gain insight into why individuals want to travel and what makes them travel. In the early stage of travel motivation study, Lundberg (1971) deployed 18 motivational attributes that are summarized in four categories: educational and cultural motivations, escape and pleasurable motivations, ethnic motivations, and sundry motivations. Dann (1977) later identified sociological tourist motivations, two push factors that entail (1) anomie-a sense of estrangement from the origin society, and (2) ecoenhancement, which is akin to self-esteem. Dann (1977) stated that these push factors predispose individuals to palliate the former and boost the later through their travel activities. Crompton (1979), applying Dann's (1977) theorem, classified seven push factors (sociopsychological motives) and two pull factors (cultural motives). Push factors are the intrinsic driving forces or desires (e.g., escape, relaxation, learning) in which tourists are compelled to make decisions about travel, whereas pull factors are those external forces that influence how tourists perceive the attractiveness of a particular tourist destination (e.g., theme parks) when deciding where to travel (Crompton, 1979; Dann, 1977, 1981). Since the inception of push-pull theory, a number of studies (e.g., Cha, McCleary, \& Uysal, 1995) have investigated tourist motivations according to these two factors. For example, Pearce and Lee (2005) revealed various motivational domains, including novelty escape/relax, relationships, autonomy, nature, selfdevelopment, stimulation, self-actualization, isolation, nostalgia, romance, and recognition. Within these domains, self-development (e.g., engaging in different cultural experiences) and nature-seeking motivation (e.g., viewing the scenery and being close to nature) were considered as critical motivations for more experienced tourists (Pearce \& Lee, 2005).

Motivation studies pertaining to nature-based destinations have sporadically appeared in the literature. Eagles (1992) investigated ecotourist motivations and compared those with the motivations of tourists in general. These findings show that compared to general tourists, ecotourists tend to have more attraction-based motivations, such as that of the wilderness, water-based activities, mountains, national parks, and rural areas (Eagles, 1992). In a similar vein, Uysal, McDonald, and Martin (1994) examined motivations of Australian tourists to US national parks and nature areas. From 30 motivational assessments, they identified five that include (1) enhancement of kinship relationships, (2) escape, (3) novelty, (4) relaxation/hobbies, and (5) prestige. Of these, novelty is the most important motivation for the tourists visiting such areas. Beyond the discussions on the underlying psychological traits of individuals, these motivation attributes have been further used as the base for segmentation research. Lang and O’Leary (1997) profiled Australian nature-based tourists according to the combination of motivation, activity participation, and destination preference, and consequently discovered six segments: (1) escape and relax vacationers, (2) family vacationers, (3) indifferent travelers, (4) nature tourists, (5) physical challenge seekers, and (6) culture and entertainment seekers. Kerstetter, Hou, and Lin (2004) analyzed 16 motivational factors of Taiwanese ecotourists, and unveiled three motivational dimensions: adventure, education, and holistic. These three factors have been further utilized to partition the tourists into three segments: (1) experience tourists, (2) learning tourists, and (3) ecotourists. Beh and Bruyere (2007) also discovered eight travel motivations of tourists visiting three of North-Central Kenya's national reserves and identified three tourists segments: escapists, learners, and spiritualists. Table 1 summarizes motivation studies on nature-based tourism. Most of these studies were conducted in national parks or a different class of federal lands. This study, however, selects one country, Norway, as the site for studying nature-based tourism. Norway 
Table 1

Summary of Motivation Studies on Nature-Based Tourism

\begin{tabular}{|c|c|c|c|}
\hline Author(s) (Year) & Respondent & Study Site & Motivation \\
\hline Beh and Bruyere (2007) & $\begin{array}{l}465 \text { tourists visiting } \\
\text { one of three reserves }\end{array}$ & $\begin{array}{l}\text { Samburu, Buffalo } \\
\text { Springs, and Shaba } \\
\text { national reserves } \\
\text { (Kenya) }\end{array}$ & $\begin{array}{l}\text { Escape; culture; personal growth; } \\
\text { mega-fauna; adventure; learning; } \\
\text { nature; general viewing }\end{array}$ \\
\hline Eagles (1992) & $\begin{array}{l}\text { 11,500 Canadian } \\
\text { tourists }\end{array}$ & Unknown & $\begin{array}{l}\text { Family togetherness; social connection; } \\
\text { escape; safety weather; nature activities }\end{array}$ \\
\hline $\begin{array}{l}\text { Kerstetter, Hou, } \\
\text { and Lin (2004) }\end{array}$ & $\begin{array}{l}460 \text { tourists visiting } \\
\text { three study sites }\end{array}$ & $\begin{array}{l}\text { Guan-Du, Gao-Mei, } \\
\text { and Ghi-gu, coastal } \\
\text { wetlands (Taiwan) }\end{array}$ & $\begin{array}{l}\text { Adventure; escape; novelty; friend and } \\
\text { family togetherness; education; } \\
\text { being in natural setting; } \\
\text { physical health; conducting a survey }\end{array}$ \\
\hline $\begin{array}{l}\text { Kruger and } \\
\text { Saayman (2010) }\end{array}$ & $\begin{array}{l}\text { 2,899 tourists in Kruger } \\
\text { park/829 tourists in } \\
\text { Tsitisikamma } \\
\text { national parks }\end{array}$ & $\begin{array}{l}\text { Kruger and Tsitsikamma } \\
\text { national parks } \\
\text { (South Africa) }\end{array}$ & $\begin{array}{l}\text { Knowledge seeking; activities; } \\
\text { park attributes; nostalgia; novelty; } \\
\text { escape; relaxation }\end{array}$ \\
\hline Lang and O’Leary (1997) & $\begin{array}{l}\text { 1,032 Australian nature } \\
\text { travelers }\end{array}$ & Unknown & $\begin{array}{l}\text { Adventure, family togetherness, } \\
\text { culture/entertainment; being in nature; } \\
\text { relaxation; escape }\end{array}$ \\
\hline Luo \& Deng (2008) & $\begin{array}{l}335 \text { visitors in the } \\
\text { study site }\end{array}$ & $\begin{array}{l}\text { Zhangjiajie national } \\
\text { forest park (China) }\end{array}$ & $\begin{array}{l}\text { Novelty-self-development; return to } \\
\text { nature; knowledge and fitness; escape }\end{array}$ \\
\hline Mehmetoglu (2007) & $\begin{array}{l}170 \text { tourists at two } \\
\text { attractions }\end{array}$ & $\begin{array}{l}\text { Two wilderness centers } \\
\text { (Northern Norway) }\end{array}$ & $\begin{array}{l}\text { Nature; physical activities; novelty/ } \\
\text { learning; escape; social contact; } \\
\text { ego/status }\end{array}$ \\
\hline $\begin{array}{l}\text { Meng, Tepanon, } \\
\text { and Uysal (2008) }\end{array}$ & $\begin{array}{l}177 \text { tourists who stayed } \\
\text { at the major resort } \\
\text { hotel in the study site }\end{array}$ & $\begin{array}{l}\text { A nature-based resort } \\
\text { destination (southwest } \\
\text { Virginia, USA) }\end{array}$ & $\begin{array}{l}\text { Activities for seeing and doing; } \\
\text { relaxation/familiarity; family/friend } \\
\text { togetherness; novelty/romance }\end{array}$ \\
\hline Pan and Ryan (2007) & 205 park visitors & $\begin{array}{l}\text { Pirongia forest park } \\
\text { (New Zealand) }\end{array}$ & $\begin{array}{l}\text { Relaxation; physical health; escape; } \\
\text { friend togetherness; learning nature; } \\
\text { self-actualization }\end{array}$ \\
\hline $\begin{array}{l}\text { Tao, Eagles, and } \\
\text { Smith (2004) }\end{array}$ & $\begin{array}{l}404 \text { Taiwanese tourists } \\
\text { visiting the park }\end{array}$ & $\begin{array}{l}\text { Taroko national park } \\
\text { (Taiwan) }\end{array}$ & $\begin{array}{l}\text { Learning about nature; participating in } \\
\text { recreation activities }\end{array}$ \\
\hline $\begin{array}{l}\text { Uysal, McDonald, and } \\
\text { Martin (1994) }\end{array}$ & $\begin{array}{l}144 \text { Australian } \\
\text { travelers visiting } \\
\text { natural areas/81 } \\
\text { did not visit }\end{array}$ & $\begin{array}{l}\text { National parks and } \\
\text { natural areas (USA) }\end{array}$ & $\begin{array}{l}\text { Relaxation/hobbies; novelty; } \\
\text { enhancement of kinship relationship; } \\
\text { prestige; escape }\end{array}$ \\
\hline
\end{tabular}

is famous for its natural environments, such as the fjords (Norway Official Travel Guide, http://www. visitnorway.com/), making it a useful tourist destination to investigate.

\section{Studies Relevant to Swedish Tourists}

Concerning the characteristics of the population under investigation in the present study, Mykletun, Crotts, and Maykeletun (2001) reported that Swedish tourists are the highest spenders in Denmark, compared to Danish and German tourists. Fredman and Emmelin (2001), in a segmentation study, labeled three groups of Swedish nature-based tourists as neutralists, purists, and urbanists. Their study characterized purists as middle-aged overnight male hikers, with canoeing and fishing as their primary activities, while urbanists are generally older women, with day hikes as their major activity. Additionally, the purists' environment attributes include placing a higher worth on the forests and watercourses in the experience of different nature environments. Wurzinger and Johansson (2006) also investigated Swedish ecotourists' and nature tourists' environmental concerns and their knowledge of ecotourism. The results show that Swedish ecotourists and nature tourists demonstrate a significantly higher level of environmental beliefs 
and concern than city tourists (Wurzinger \& Johansson, 2006). These ecotourists and nature tourists also exhibit more proenvironmental behavior than city tourists (Wurzinger \& Johansson, 2006).

In sum, empirical studies of tourism motivation have been expanded from a psychological perspective (Crompton, 1979) to a nature-based tourism context (Beh \& Bruyere, 2007; Eagles, 1992; Kerstetter, Hou, \& Lin, 2004; Lang \& O’Leary, 1997; Luo \& Deng, 2008; Uysal et al., 1994). Nevertheless, it is plausible that new investigations of tourist motivation relevant to those destinations (e.g., Scandinavian regions), highly regarded as a place with enormous natural resource and unique landscapes, could be further deployed.

\section{Purpose of Study}

Although tourism scholars have studied naturebased tourism in the last two decades, it is not clear if all visitors are attracted by nature. It may be assumed that the attitudes of tourists in exploring nature will vary. For example, some may be highly interested in engaging with nature and some may show a low motive toward involvement in natural environments. It is thus plausible to further examine the characteristics of travelers who hold different levels of motivation toward exploring nature. To address this issue, this research attempts to understand the characteristics of traveler segments possessing a different level of trip motivation toward nature. This article uses a case study approach that focuses on the trip behaviors of a single nationality visiting Norway, a country that is well known for spectacular scenery and nature based activities (Gössling \& Hultman, 2006; Snyder \& Stonehouse, 2007).

\section{Methods}

The present study utilizes a secondary data set collected by Innovation Norway in 2009. The data set aims to investigate the inbound travel market concerning nature-based tourism in Norway. To address the potential of nature-based travelers to Norway, the data collection is based on a sequential procedure of three phases. In a first research step, a phone interview procedure with Swedish residents was performed to reveal if the respondent was interested in nature-based tourism. In this phase,
$73 \%$ of Swedish residents in Sweden were found to fall within the nature-based group. Consequently, an online survey was mailed to respondents interested in nature-based vacations. An online survey was utilized as the primary data collection method because of its ability to reach a large number of individuals throughout Sweden in a timely but not costly manner (Van Selm \& Jankowski, 2006).

Lastly, within this online survey, a screening procedure further identified those who might potentially visit Norway within 3 years for a nature-based vacation, and those who have taken a holiday within the last 3 years. In sum, the online respondents asked to complete all study questions were viewed as potential outbound travelers to Norway. Finally, the online survey was able to retrieve responses from 2,034 Swedish residents, aged 15 years and older, who expressed an interest in taking a naturebased vacation in Norway.

According to Statistics Norway (http://www. ssb.no/), the Swedish accounted for approximately 900,000 personal night stays in Norway in 2010. These travelers are the second largest foreign traveler group (next to Germans), consisting of $12 \%$ of inbound travelers to Norway. Motivation questions were measured by a Likert-type scale from 1 (not suitable) to 7 (fits completely). The nature-related motivation variables are to: (1) experience the beautiful Norwegian nature, (2) be active in nature, (3) travel in a country that takes the environment seriously, and (4) get close to nature.

A $K$-means cluster analysis was first employed for segment revelation, followed by descriptive, univariate, and multivariate analyses at the stage of segment diagnoses. In the segment diagnoses stage, univariate and multivariate analyses were used to detect if there were significant differences among resultant clusters. Descriptive analyses were performed to unveil if there were any differences in demographic characteristics and the likelihood of engaging in specific activities, which were also assessed by a 5-point Likert-type scale ( 1 = definitely not, 2 = probably not, 3 = maybe, 4 = probably, 5 = definitely).

\section{Findings}

Three mutually exclusive clusters emerged from the cluster analysis using the four nature-related 
motivations as the analytical base. The first cluster included 748 respondents, the second cluster consisted of 942, and the third cluster was comprised of 344 . They represented $37 \%, 46 \%$, and $17 \%$ of the total samples, respectively. A multivariate analysis of variance (MANOVA) procedure further examined whether the three resultant clusters differed significantly concerning their nature-related motivations. The study found significant differences among the three groups in regard to the four naturerelated motivations: (1) to experience the beautiful Norwegian nature $[F(2,2031)=954.68, p<0.001]$, (2) to be active in nature $[F(2,2031)=1,097.40$, $p<0.001$ ], (3) to travel in a country that takes the environment seriously $[F(2,2031)=525.37, p<$ $0.001]$, and (4) to get close to nature $[F(2,2031)=$ 1448.27, $p<0.001$ ].

Cluster I had the highest mean scores on all motivational variables, while Cluster III possessed the lowest means scores overall (see Table 2 and Fig. 1). The mean scores of motivation in Cluster I were all above 5. In Cluster III, all means scores were lower than 3.5. For Cluster II, three motivational attributes had a mean score over 4 . Based on those mean scores, the study showed that Cluster III was not fully attracted by nature when visiting Norway, whereas Cluster I was utterly enticed by nature in Norway. Cluster II had mixed feelings about immersing with nature in Norway. For example, the respondents from this cluster were not likely to "be active in nature.” Nevertheless, because the means scores of this cluster were all above 3.5, this cluster showed, on a smaller scale, a tendency to engage with nature.

Concerning the relative importance of four naturebased motivations, all clusters viewed "experience the beautiful Norwegian nature" as the most important nature-related motivation for their nature-based tourism (see Table 2). Clusters I and II viewed "get close to nature" as the second important travel motivation to a nature destination. Further, "use my body and be active in nature" was the lowest ranked motivation, portraying a different level of desire to engage with nature than the other clusters. For example, Clusters II and III possessed a lower desire to be active in nature. The above findings suggest that Cluster I travelers could be best portrayed as Hardcore Explorers, Cluster II as Typical Participants, and Cluster III as Casual Participants.

In sum, the majority (83\%) of Swedish residents could be illustrated as hardcore or typical travelers as measured by their nature-related travel motivations. Since the respondents from Cluster III regarded "experience the beautiful Norwegian nature" as the most important nature-related motivation, and "use my body and be active in the nature" as the least important one, the novelty of seeking nature scenery could be the defining attribute attracting those with a marginal interest in participating in nature-related activities.

To cross-validate the three resultant clusters, this study further analyzed if there are differences in demographic traits among the clusters. The demographic characteristics of clusters are presented in Table 3. Significant differences were found in gender $\left(X^{2}=16.84, p<0.001\right)$, education level $\left(x^{2}=\right.$ $14.51, p<0.05)$, and marital status $\left(x^{2}=31.51\right.$, $p<0.001$ ) within these groups of travelers. Married/ cohabitant couples appear to be the most common demographic characteristic among the three clusters, followed by those who are single or live with partners. Nevertheless, age and household income did

Table 2

Resultant Clusters Based on Four Nature-Related Motivations

\begin{tabular}{lccc}
\hline Nature-Related Motivation & Cluster I $(n=748)$ & Cluster II $(n=942)$ & Cluster III $(n=344)$ \\
\hline $\begin{array}{l}\text { Experience the beautiful } \\
\text { Norwegian nature }\end{array}$ & $6.51(0.84)$ & $5.78(1.04)$ & $3.42(1.61)$ \\
$\begin{array}{l}\text { Use my body and be active } \\
\text { in nature }\end{array}$ & $5.74(1.08)$ & $3.63(1.28)$ & $2.35(1.31)$ \\
$\begin{array}{l}\text { Travel in a country that takes } \\
\text { the environment seriously }\end{array}$ & $5.45(1.39)$ & $4.02(1.40)$ & $2.57(1.50)$ \\
\begin{tabular}{l} 
Get close to nature \\
\hline
\end{tabular}
\end{tabular}

Values are mean with SD in parentheses. 


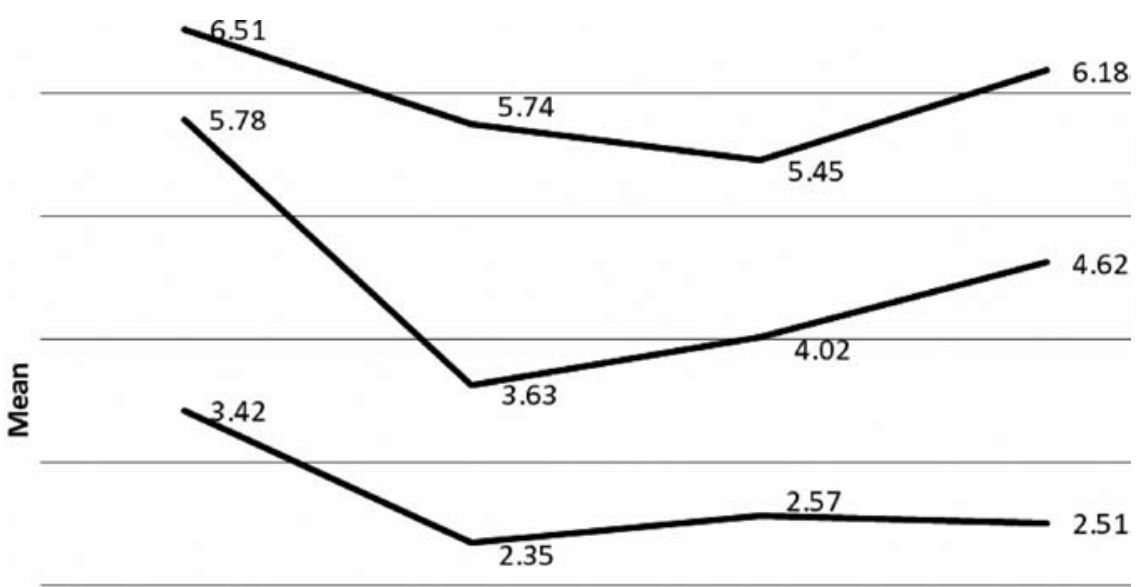

1

2

3

4

Figure 1. The line chart of the clusters' means. Cluster I: top line; Cluster II: middle line; Cluster III: bottom line. $1=$ Experience the beautiful Norwegian nature; 2 = Use my body and be active in nature; $3=$ Travel in a country that takes the environment seriously; 4 = Get close to nature.

not show any significant differences. Concerning these demographic traits, Cluster III tended to be male while Cluster I and Cluster II included more females. Cluster III was likely to have education at or above college level. Cluster II had the largest percentage of married/cohabitant couples.

Further, this study analyzed whether there are any differences among the three clusters concerning the likelihood of participating in the six nature-related activities when choosing an international trip in the next 3 years. Consequently, a MANOVA procedure found that significant differences exist among the clusters $(F=44.65, p<0.00)$. The activity concerning "recreation and relaxation in the nature" was the top rated component among all clusters. Cluster I (Hardcore Explorer) demonstrated the strongest intention to pursue four out of six activities. Those are (1) hiking in nature, (2) being active in nature experience, (3) recreation and relaxation in nature, and (4) enjoying the snow in the winter. However, the other two clusters of Typical Participant and Causal Seeker topped others in their desire to participate in one activity. Specifically, among the three clusters, the Typical Participant was most likely to pursue activities in the Arctic, and the Causal Seeker showed the strongest desire to take a cruise. Experiencing the northern lights in the winter and midnight sun in the summer, visiting fjords with tall mountains, and touring around idyllic fishing villages are the Arctic-related activities that require less effort. Since the Typical Participant did not tend to be active in nature (see Table 2), the above activities might serve the needs of this group of travelers. Taking a cruise to Norway could certainly expose passengers to some popular aspects of Norwegian nature. It is not surprising to learn that the Causal Seeker had the highest interest in taking a cruise, because they demonstrated the lowest motivation to be active in nature while appreciating the beautiful Norwegian environment. This result further cross-validated the mindset of the Causal Seeker.

Table 5 summarizes the main characteristics of the three resulting clusters. For example, the Typical Participants make up $46.3 \%$ of the respondents. Males and females are seemingly distributed 
Table 3

Demographic Traits of Resultant Clusters

\begin{tabular}{|c|c|c|c|c|c|}
\hline Characteristics & $\begin{array}{l}\text { Cluster I }(n=748) \\
\text { Hardcore Explorer }\end{array}$ & $\begin{array}{l}\text { Cluster II }(n=942) \\
\text { Typical Participant }\end{array}$ & $\begin{array}{l}\text { Cluster III }(n=344) \\
\text { Casual Seeker }\end{array}$ & $x^{2}$ & $p$ \\
\hline Gender & & & & 16.8 & $0.001 *$ \\
\hline Male & 325 (43.4\%) & 469 (49.8\%) & $194(56.4 \%)$ & & \\
\hline Female & $423(56.6 \%)$ & $473(50.2 \%)$ & $150(43.6 \%)$ & & \\
\hline Education level & & & & 14.5 & $0.005 *$ \\
\hline Secondary education & $45(6.0 \%)$ & $68(7.2 \%)$ & $34(9.9 \%)$ & & \\
\hline Further education & $255(34.1 \%)$ & $364(38.7 \%)$ & $140(40.7 \%)$ & & \\
\hline College education & $234(31.3 \%)$ & $281(29.8 \%)$ & $90(26.2 \%)$ & & \\
\hline Postgraduate education & $214(28.6 \%)$ & $229(24.3 \%)$ & $80(23.2 \%)$ & & \\
\hline Marital status & & & & 31.5 & $0.001 *$ \\
\hline Married/cohabitated couple & $494(66 \%)$ & $636(67.5 \%)$ & $207(60.2 \%)$ & & \\
\hline Living with friends & $6(0.8 \%)$ & $4(0.4 \%)$ & $2(0.6 \%)$ & & \\
\hline Single/living with partner & $151(20.2 \%)$ & $155(16.5 \%)$ & $68(19.8 \%)$ & & \\
\hline Living with parents & $26(3.5 \%)$ & $48(5.1 \%)$ & $30(8.7 \%)$ & & \\
\hline Others & $5(0.7 \%)$ & $17(1.8 \%)$ & $12(3.5 \%)$ & & \\
\hline
\end{tabular}

${ }^{*} p<0.01$.

equally in each cluster, yet females are the majority in the groups of Hardcore Explorers (56.6\%) and Typical Participants (50.2\%), while males represent the majority in the cluster of Casual Seekers (56.4\%). For education attainment, the majority of Casual Seekers (51\%) have education below college level. In addition, the majority of Hardcore Explorers (60\%) and Typical Participants (54\%) have college-level education or above. Across all three clusters, most respondents are married or cohabitating couples.

\section{Conclusions}

This study indicates that Swedish tourists traveling to Norway in the last 3 years may be divided into three distinct groups according to four nature-based motivations: Cluster I is portrayed as the Hardcore Explorer, Cluster II as the Typical Participant, and Cluster III as the Casual Seeker. Furthermore, Typical Participants represent the largest group (46\%) of respondents, whereas Casual Participants are the smallest group (13\%). It is enlightening to find that Hardcore Explorers show a low intention to take a cruise, so as to not seek the so-called Arctic experience that may be represented by viewing the midnight sun and northern lights, considered passive recreational activities. In this study, slightly over one third (37\%) of Swedish residents are Hardcore Explorers, which may provide promising marketing implications for Norwegian tour operators. In the mind of Swedish residents, Norway seems to be an ideal foreign county for enjoying serious naturerelated activities. The Typical Participant group,

Table 4

ANOVA of Nature-Based Activities $(N=2,034)$

\begin{tabular}{lccccc}
\hline Activity & $\begin{array}{c}\text { Cluster I } \\
(n=748)\end{array}$ & $\begin{array}{c}\text { Cluster II } \\
(n=942)\end{array}$ & $\begin{array}{c}\text { Cluster III } \\
(n=344)\end{array}$ & $F$ & $p$ \\
\hline Hiking in nature & 3.56 & 2.92 & 2.36 & 199.94 & $<0.00^{*}$ \\
Be active in natured-based experience & 3.67 & 3.05 & 2.35 & 192.95 & $<0.00^{*}$ \\
Recreation and relaxation in nature & 3.71 & 3.29 & 3.74 & 138.18 & $<0.00^{*}$ \\
Winter with snow & 3.02 & 2.59 & 2.47 & 30.97 & $<0.00^{*}$ \\
Arctic experiences & 2.04 & 2.81 & 1.70 & 25.78 & $<0.00^{*}$ \\
Cruise & 2.51 & 2.52 & 2.67 & 3.05 & $<0.05^{*}$ \\
\hline
\end{tabular}

Based on a scale where 1 = definitely not; 2 = probably not; 3 = maybe 4 = probably; 5 = definitely. 
Table 5

Cluster Profiles

\begin{tabular}{|c|c|}
\hline Clusters & Characteristics \\
\hline $\begin{array}{l}\text { Cluster I: } \\
\text { Hardcore Explorer }\end{array}$ & $\begin{array}{l}36.8 \% \text { of respondents } \\
\text { Female (56.6\%) } \\
\text { College education or above (60\%) } \\
\text { Married or cohabitated couple (66\%) } \\
\text { Most likely to hike in nature, be active } \\
\text { in nature-based experience, and enjoy } \\
\text { winter with snow }\end{array}$ \\
\hline $\begin{array}{l}\text { Cluster II: } \\
\text { Typical Participant }\end{array}$ & $\begin{array}{l}46.3 \% \text { of respondents } \\
\text { Female }(50.2 \%) \\
\text { College education or above }(54.1 \%) \\
\text { Married or cohabitated couple }(67.5 \%) \\
\text { Most likely to enjoy arctic experience }\end{array}$ \\
\hline $\begin{array}{l}\text { Cluster III: } \\
\text { Casual Seeker }\end{array}$ & $\begin{array}{l}\text { 16.9\% of respondents } \\
\text { Male (56.4\%) } \\
\text { Education below college (50.8\%) } \\
\text { Married or cohabitated couple (60.2\%) } \\
\text { Most likely to enjoy recreation and } \\
\text { relaxation in nature and cruise }\end{array}$ \\
\hline
\end{tabular}

the largest among Swedish residents, also shows a moderate interest in nature-related activities. In total, these two groups represent $83 \%$ of Swedish residents. As a result, Swedish residents should be regarded as viable inbound travelers to Norway.

The study findings are in congruence with the study by Mehmetoglu (2007), which confirmed that not everyone visiting nature-based attractions and destinations is highly interested in naturerelated activities. Mehmetoglu (2007) further articulated that some cultural and pleasure elements should be added to the tourism-related products in nature-based attractions. In the current study, the Casual Seeker segment presents a lower motivation to experience beauty in natural or be active in nature. As this study illustrates, low nature-minded groups are most likely to enjoy certain recreation and relaxation activities in nature. Thus, to respond to the expectations of this segment, service providers may supply additional passive or enhanced recreational activities.

This study finds that, overall, the Swedish are unlikely to visit Norway for the Arctic experience, yet also have a low desire to take a cruise, based on the mean scores of the above variables that are below 3. The findings may be explained by the following two viewpoints. Sweden is one of eight Arctic nations with territory above the Arctic
Circle. Some traveler activities offered in the Norwegian Arctic may be provided in the Swedish Arctic as well. Further, due to a short distance of travel from Sweden to Norway, the Swedish could easily visit nature-based destinations via various modes of transportation with less cost, such as tour buses, personal cars, and air travel.

Concerning activity patterns, the study finding slightly differs from that of the ecotourism study by Wight (1996), who found hiking to be the most popular tourist activity. Instead of hiking, the most popular activities for nature-minded tourists are relaxing and enjoying recreational activities in nature. This difference in preference can perhaps be attributed to Norway's unique natural environment, which supplies diverse venues to freely engage with nature.

Lastly, it is important to consider the limitation of this study. This study assesses four nature-based motivations that might not be comprehensive. Because this study is an exploratory study of nature-based motivations, the revelation of Swedish segments has served the study aim well. Nevertheless, future research may consider enhancing the construct validity of the scale to broaden the scope of measurement concerning nature-based motivations when necessary. This study used a secondary data set, generated from an online survey, to evaluate travel patterns of the Swedish. It may not truly reflect the opinions of the entire group of Swedish travelers. For example, populations who do not have access to the Web or do not feel comfortable filling out online surveys are excluded from the study. Moreover, it is important to note that the Swedish visitors to Norway may not have nature-based tourism as their primary travel motivation, although nature-based tourism is part of their motivation when visiting Norway.

\section{References}

Beh, A., \& Bruyere, B. L. (2007). Segmentation by visitor motivation in three Kenyan national reserves. Tourism Management, 28, 1464-1471.

Butler, R. W. (1994). Tourism in the Canadian Arctic: Problems of achieving sustainability. In C. Kempf \& L. Girard (Eds.), Tourism in Polar regions. Proceedings of the symposium, Colmar, France, April 21-23, 1992.

Cha, S., McCleary, K. W., \& Uysal, M. (1995). Travel motivations of Japanese overseas travelers: A factor-cluster segmentation approach. Journal of Travel Research, 34(1), 33-39. 
Crawford, D. W., Jackson, E. L., \& Godbey, G. (1991). A hierarchical model of leisure constraints. Leisure Sciences, 13(4), 309-320.

Crompton, J. L. (1979). Motivations for pleasure vacation. Annals of Tourism Research, 6(4), 408-424.

Dann, G. M. S. (1977). Anomie, ego-enhancement and tourism. Annals of Tourism Research, 4(4), 184-194.

Dann, G. M. S. (1981). Tourism motivations: An appraisal. Annals of Tourism Research, 8(2), 189-219.

Dolnicar, S., \& Leisch, F. (2008). Selective marketing for environmentally sustainable tourism. Tourism Management, 29(4), 672-680.

Eagles, P. F. J. (1992). The travel motivations of canadian ecotourists. Journal of Travel Research, 3(2), 3-7.

Filion, F. L., Foley, J. P., \& Jacquemot, A. J.(1994). The economics of global ecotourism. Protected area economics and policy: Linking conservation and sustainable development (pp. 235-252). Washington, DC: World Bank.

Fredman, P., \& Emmelin, L. (2001). Wilderness purism, willingess to pay and management preferneces: A study of Swedish mountain tourism. Tourism Economics, 7(1), 5-20.

Goodwin, H. (1996). In pursuit of ecotourism. Biodiversity and conservation, 5(3), 277-291.

Gössling, S., \& Hultman, J. (2006). Ecotourism in Scandinavia: Lessons in theory and practice. Wallingford, UK: CAB International.

Hull, R. B., \& Harvey, A. (1989). Explaining the emotion people experience in suburban parks. Environment \& Behavior, 21, 323-345.

Kerstetter, D. L., Hou, J., \& Lin, C. (2004). Profiling taiwanese ecotouriss using a behavioral approach. Tourism Management, 25, 491-498.

Kruger, M., \& Saayman, M. (2010). Travel motivation of tourists to Kruger and Tsitsikamma national parks: A comparative study. South African Journal of Wildlife Research, 40(1), 93-102.

Lang, C. T., \& O’Leary, J. T. (1997). Motivation, participation, and preference: A multi-segmentation approach of the Australian nature travel market. Journal of Travel \& Tourism Marketing, 6(3-4), 159-180.

Lundberg, D. E. (1971). Why tourists travel. Cornell HRA Quarterly, 11(4), 75-81.

Luo, Y., \& Deng, J. (2008). The new environmental paradigm and nature-based tourism motivation. Journal of Travel Research, 46(4), 392-402.

Mehmetoglu, M. (2007). Typologising nature-based tourists by activity: Theoretical and practical implications. Tourism Management, 28(3), 651-660.

Meng, F., Tepanon, Y., \& Uysal, M. (2008). Measuring tourist satisfaction by attribute and motivation: The case of a nature-based resort. Journal of Vacation Marketing, 14(1), 41-56.

Mykletun, R. J., Crotts, J. C., \& Mykletun, A. (2001). Positioning an island destination in the peripheral area of the
Baltics: A flexible approach to market segmentation. Tourism Management, 22, 493-500.

Nyanpane, G. P. (2007). Ecotourism versus nature-based tourism: Do tourists really know the difference? Anatolia: An International Journal of Tourism and Hospitality, 18, 161-165.

Nyaupane, G. P., Morais, D. B., \& Graefe, A. R. (2004). Nature tourism constraints: A cross-activity comparison. Annals of Tourism Research, 31, 540-555.

Pan, S., \& Ryan, C. (2007). Mountain areas and visitor usage-motivations and determinants of satisfaction: The case of Pirongia forest park, New Zealand. Journal of Sustainable Tourism, 15, 288-208.

Pearce, P., \& Lee, U. L. (2005). Developing the travel career approach to tourist motivation. Journal of Travel Research, 43, 226-237.

Pennington-Gray, L. A., \& Kerstetter, D. L. (2002). Testing a constraints model within the context of nature-based tourism. Journal of Travel Research, 40, 416-423.

Silverberg, K. E., Backman, S. J., \& Backman, K. F. (1996). A preliminary inverstigation into the psychographics of nature-based travelers to the Southeastern United States. Journal of Travel Research, 35, 19-28.

Snyder, J., \& Stonehous, B. (2007). Prospects for polar tourism. Wallingforad, UK: CAB International.

Tangeland, T., Vennesland, B., \& Nybakk, E. (2013). Second-home owners' intention to purchase naturebased tourism activity products-A Norwegian case study. Tourism Management, 36, 364-376.

Tao, C., Eagles, P. F. J., \& Smith, S. L. J. (2004). Profiling Taiwanese ecotourists using a self-definition approach. Journal of Sustainable Tourism, 12(2), 149-168.

The International Ecotourism Society. (1990). What is ecotourism. Retrieved October 18, 2011, from http://www. ecotourism.org/what-is-ecotourism

The International Ecotourism Society. (2000). Ecotourism statistical fact sheet. Washington, DC: Author.

Uysal, M., McDonald, C. D., \& Martin, B, S. (1994). Australian visitors to US national parks and natural areas. International Journal of Contemporary Hospitality Management, 6(3), 18-24.

Valentine, P. (1992). Review: Nature-based tourism. London: Belhaven Press.

Valentine, P. (1993). Ecotourism and nature conservation: A definition with some recent developments in Micronesia. Tourism Management, 14, 107-115.

Van Selm, M., \& Jankowski, N. W. (2006). Conducting online surveys. Quality \& Quantity, 40(3), 435-456.

Vickerman, S. (1988). Stimulating tourism and economic growth by featuring new wildlife recreation opportunities. Transactions of the North American Wildlife and Natural Resources Conference, 414-423.

Viken, A. (1993). The Arctic tourist experience. The Fifth World Wilderness Conference, Arctic Tourism and Ecotourism Symposium, Tromso, Norway, September 24-October 1. 
Wight, P. A. (1996). North Amerian ecotourism markets: Motivations, references, and destinations. Journal of Travel Research, 35, 3-10.

World Tourism Organization. (1998). Ecotourism: Now one-fifth of market. World Tourism Organization News, January/February. Retrieved 18 October 2011 from http://www.worldtourism.org/omt/newslett/janfeb98/ ecotour.htm.
Wurzinger, S., \& Johansson, M. (2006). Environmental concern and knowledge of ecotourism among three groups of swedish tourists. Journal of Travel Research, $45,217-226$.

Young, M. (1999). The relationship between tourist motivations and the interpretation of place meaning. Tourism Geographies, 1(4), 387-405. 